\title{
SISTEM PAKAR PENENTUAN MAKANAN PENDAMPING AIR SUSU IBU MENGGUNAKAN METODE MIN MAX DAN NAÏVE BAYES
}

\author{
${ }^{1}$ Acihmah Sidauruk, ${ }^{2}$ Abdullah \\ Sistem Informasi, Fakultas Ilmu Komputer, Universitas Amikom Yogyakarta, \\ Jl Ringroad Utara, Condong catur, Depok, Sleman 55283 \\ ${ }^{2}$ Program Studi Sistem Informasi, Universitas Islam Indragiri, Tembilahan \\ Jl. Provinsi Parit 1 Tembilahan Indragiri Hilir Riau \\ Email:acihmah@amikom.ac.id, abdialam@yahoo.com
}

(Diterima: 4 September 2019, direvisi: 7 Desember 2019, disetujui: 03 Januari 2020)

\begin{abstract}
Babies are special gifts from God. Babies' age is around 0-24 months old. They experience physical changes and rapid growth along with the intake of nutritional needs. Therefore, good feeding given by their mother will influence their growth. For this reason, a mother should aware of the importance of providing complimentary food intake besides breast milk. It can be given depends on the appropriate age, its frequency, amount, texture, active, responsive and hygienic. The main discussion in this research was to determine complementary foods for babies by implementing an Expert System. The development of this expert system used the Min Max and Naive Bayes methods, which are methodologies of facts or knowledge to get a conclusion. These methods were done by searching the data application and input information to get a conclusion. Algorithm testing was done using a confusion matrix. The results of this study showed that 20 respondents with the Naive Bayes algorithm and Nä̈ve Bayes with Min-Max were successfully provided recommendations 18 of 20 data following the results of recommendations from experts. Bayes algorithm had an accuracy value, that was $95.83 \%$, a precision value was $95 \%$ and a recall value was $95 \%$ in providing recommendations for complementary foods.
\end{abstract}

Keywords: MP-ASI, Expert system, Nä̈ve Bayes

\begin{abstract}
ABSTRAK
Bayi merupakan seorang makhluk hidup anugrah dari tuhan. Makhluk hidup disebut bayi ketika usia 0-24 bulan, bayi mengalami perubahan fisik dan pertumbuhan secara cepat seiring dengan asupan kebutuhan gizinya, pada saat masa pertumbuhan bayi akan sangat bergantung pada pemberian makanan yang diberikan oleh ibunya. Oleh karena itu seorang ibu harus mengetahui pentingnya memberikan asupan makanan untuk mendampingi ASI sesuai waktu yang telah ditentukan, frekuensi, jumlah, tekstur, aktif, responsif dan higiens. Pembahasan utama dalam penelitian ini adalah menentukan makanan pendamping ASI pada Bayi dengan menerapkan Sistem Pakar . Adapun pengembangan sistem pakar ini menggunakan metode min max dan naive bayes, yang mana metodologi dari fakta atau pengetahuan untuk menarik suatu kesimpulan. Cara kerja metode ini dilakukan dengan pencarian yang melalui penerapan data-data dan informasi masukkan dahulu dan akan menuju suatu kesimpulan. Pengujian Algoritma menggunakan confusion matrix. Hasil dari penelitian adalah hasil uji pada 20 responden dengan algoritma naive bayes dan naïve bayes dengan Min-Max berhasil memberikan rekomendasi 18 dari 20 data yang sesuai dengan hasil rekomendasi dari pakar. Algoritma bayes memiliki nilai akurasi sebesar 95,83\%, nilai presisi sebesar $95 \%$ dan nilai recall sebesar 95\% dalam memberikan rekomendasi jenis makanan pendamping ASI.
\end{abstract}

Kata Kunci: MP-ASI, Sistem pakar, Naïve Bayes

\section{PENDAHULUAN}

Kemajuan teknologi yang semakin tinggi dan pesatnya penelitian dalam pengembangan ilmu untuk masyarakat luas, diperlukannya suatu media perantara dari para peneliti kepada masyrakat secara merata. Khususnya pengetahuan ibu-ibu untuk menentukan Makanan Pendamping Air Susu Ibu (MPASI) pada asupan makan untuk bayi semakin dibutuhkan, untuk mencukupi kebutuhan gizi 
pada bayi yang lebih optimal. Oleh karena itu ibu harus lebih memperhatikan dan mengetahui asupan makanan pada bayi. Selain itu ketepatan dalam waktu pemberian MPASI pun mempengaruhi dalam kecukupan nutrisi pada bayi. Makanan pendamping air susu ibu adalah makanan ataupun minuman yang diberikan kepada bayi ataupun pada anak usia 6 bulan sampai dengan 24 bulan untuk memenuhi kebutuhan gizi selain Air Susu Ibu (ASI) [1].

Sistem kekebalan tubuh bayi yang belum sempurna pada usia di bawah 6 bulan. Pemberian MPASI pada usia di bawah 6 bulan sama halnya memberi peluang terjangkit banyak jenis kuman, terlebih jika disajikan secara tidak higienis. Selain itu pemberian asupan sebelum 6 bulan akan mempersulit ibu dalam mempertahankan produksi ASI. Hal tersebut disebabkan karena bayi yang sudah mendapatkan MPASI kebutuhan menyusunya cenderung berkurang. Waktu yang tepat untuk memberikanan makanan pendamping ASI yakni pada usia bayi 6 bulan keatas, yang mana zat gizi dari MPASI sangat dibutuhkan sebagai perlindungan besar dari berbagai penyakit [2]. Sistem pencernaan bayi siap menerima MPASI pada usia di atas 6 bulan, dikarenakan pada usia di atas 6 bulan sistem sudah terbentuk dengan relatif sempurna. Pemberian makanan di usia 6 bulan keatas juga akan menurunkan resiko alergi terhadap makanan. Penundaan pemberian MPASI sampai usia 6 bulan juga dapat memproteksi bayi dari serangan obesitas suatu saat nanti [3]. Proses memecah sari-sari makanan yang masih belum memasuki fase sempurna. Masih banyak lagi alasan mengapa MPASI hanya dapat diperkenalkan pada anak setelah memasuki usia sebelum 6 bulan.

Oleh karena itu penulis mengangkat permasalahan ini. Pertumbuhan bayi dimulai sejak 0-12 bulan, yang mana tumbuh kembang, cepatnya perubahan pada fisik bayi disertai dengan keberagaman gizi yang dibutuhkan. Pada periode ini, kebutuhan usia bayi tersebut dapat disesuaikan menggunakan suatu sistem aplikasi, sehingga membantu sang ibu dalam menentukan MPASI yang tepat untuk bayinya. Dengan latar belakang tersebut, penulis melakukan penlitian sistem pakar penentuan makanan pendamping ASI menggunakan metode Naive Bayes dan Min Max. Sistem pakar merupakan basis pengetahuan dari pakar yang diolah dengan alat bantu perangkat lunak. Metode Naive Bayes merupakan algoritma prediksi atau klasifikasi yang digunakan. Untuk melakukan Pengujian kedua metode tersebut menggunakan counfision matrix.

\section{TINJAUAN PUSTAKA}

Pada beberapa penelitian sebelumnya seperti yang dilakukan oleh Ciptohartono [4] tentang penggunaan algoritma Klasifikasi Naive Bayes untuk menilai kelayakan kredit. Data awal pada penelitian tersebut, dilakukan pre-processing sehingga mendapatkan akurasi sebesar $85.57 \%$. Pengujian yang dilakukan hanya menggunakan satu parameter yaitu akurasi saja. Penelitian lain adalah mencari perkiraan waktu training studi mahasiswa juga menggunakan algoritma Naive Bayes yang dilakukan oleh Jananto [5]. Algoritma Klasifikasi Naive Bayes digunakan pada penelitian Rahman [6]. Algoritma klasifikasi Naive Bayes digunakan untuk memprediksi ketepatan studi mahasiswa menggunakan data training dan testing. Akurasi yang tergolong kecil dengan nilai akurasi sebesar $75.57 \%$. Rahman menerapkan algoritma Naive Bayes" untuk melakukan klasifikasi tingkat kelulusan mahasiswa. Tugas klasifikasi yang dilakukan adalah untuk klasifikasi ketepatan masa studi mahasiswa. Berdasarkan hasil eksperimen diperoleh tingkat kesalahan sebesar 20\% sampai dengan 34\%. Kesalahan tersebut dapat dipengaruhi oleh jumlah data training dan testing serta tingkat konsistensi yang digunakan. Penggunaan variabel pengujian hanya sebatas IPK saja untuk melakukan prediksi. Nugroho [7] menggunakan algoritma Naive Bayes untuk klasifikasi kelulusan mahasiswa Universitas Dian Nuswantoro (UDINUS). Teknik klasifikasi dan metode algoritma Naive Bayes, digunakan untuk mengklasifikasi kelulusan mahasiswa UDINUS Fakultas Ilmu Komputer angkatan tahun 2009. Hasil penelitian menunjukkan tingkat akurasi kelulusan sebesar 82.08\%. Data yang kurang kompleks menyebabkan model dapat memprediksi cukup akurat. Penelitian yang dilakukan masih terbatas pada pengujian dengan validasi satu kali dengan parameter uji hanya menggunakan akurasi.

Jika dilihat dari beberapa studi-studi di atas yang merupakan penelitian terdahulu yang terkait, maka terdapat beberapa perbedaan antara penelitian terdahulu dengan yang dilakukan sebelumnya dengan penelitian ini. Algoritma yang digunakan pada penelitian ini adalah nä̈ve bayes dan kombinasi nä̈ve bayes min max. Penelitian terdahulu menarik kesimpulan dengan menggunakan 
parameter akurasi sedangkan untuk penelitian ini ada penambahan parameter yaitu recall dan precision.

\subsection{Sistem Pakar}

Sistem pakar adalah merupakan salah satu sistem informasi berbasis komputer dimana pada sistem ini digunakan pengetahuan, fakta, dan teknik penalaran untuk memecahkan masalah. Pemecahan persoalan sesuai dengan keahlian oleh orang yang sudah mumpuni atau pakar dalam area berkenaan [8]. Konsep dasar dari sistem pakar adalah pengguna aplikasi menyampaikan fakta untuk sistem pakar dan dari pakar akan memberikan jawaban atau berupa saran. Pada umumnya sistem pakar memiliki dua komponen penting yaitu basis data pengetahuan atau knowledge base yang berisi pengetahuan dan mesin inferensi atau inference engine digunakan unuk melakukan pencarian fakta pengetahuan dalam basis data pengetahuan [9].

\subsection{Pengertian MPASI (Makanan Pendamping ASI)}

Makanan Pendamping Air Susu Ibu (MPASI) dapat didefinisikan sebagai makanan yang dapat diberikan untuk bayi mulai umur 6 bulan dalam rangka memenuhi kebutuhan nutrisi dan energi lain, yang tidak dapat tercukupi oleh pemberian ASI saja. ASI hanya mampu memenuhi dua pertiga kebutuhan bayi pada usia 6-9 bulan, dan pada usia 9-12 bulan memenuhi setengah dari kebutuhan bayi [10]. Memberikan makanan tambahan khusus harus diperhatikan jenis makanan dan takarannya, Selain itu juga harus menyesuaikan dengan kebutuhan untuk melengkapi dan menambah nutrien, selera dan serat bayi. Serta tidak boleh dipaksakan karena akan menyebabkan gangguan pada nafsu makan bayi.

\subsection{Nä̈ve Bayes}

Metode algoritma Nä̈ve-Bayes merupakan algoritma prediksi atau klasifikasi dengan metode statistik dan probabilitas yang ditemukan oleh scientis dari Inggris yaitu Thomas Bayes. Pada pengimplementasian Bayes (Rule of Bayes) dengan memberikan asumsi ketidak tergantungan yang sangat kuat atau naif. Kelebihan dari algoritma naïve bayes adalah sederhana tetapi memiliki akurasi yang tinggi dan dapat menangani permasalahan banyak kelas [11][12].

\subsection{Evaluasi Algoritma}

Terdapat banyak ukuran dalam evaluasi performa algoritma-algoritma prediction. Ukuran-ukuan tersebut diantaranya adalah accuracy, precision dan recall [13]. Metode yang akan digunakan pada penelitian ini adalah metode evaluasi confusion matrix untuk mendapatkan masing-masing ukuran trsebut. Confusion matrix adalah visualisasi untuk mengevaluasi model klasifikasi. [14]. Evaluasi dengan confusion matrix akan menghasilkan nilai akurasi, presisi dan recall.

\section{METODOLOGI PENELITIAN}

Metode penelitian dilakukan dalam rangka mencapai tujuan penelitian. Langkah-langkan dilakukan dengan cara terstruktur yang meliputi desain sistem, penerapan algoritma, rule, model yang terkait dengan sistem. Untuk lebih jelasnya dapat dilihat alur penelitian secara umum pada sistem penentuan makanan pendamping ASI di Posyandu Kota Yogyakarta sebagaimana Gambar 1 berikut ini. 


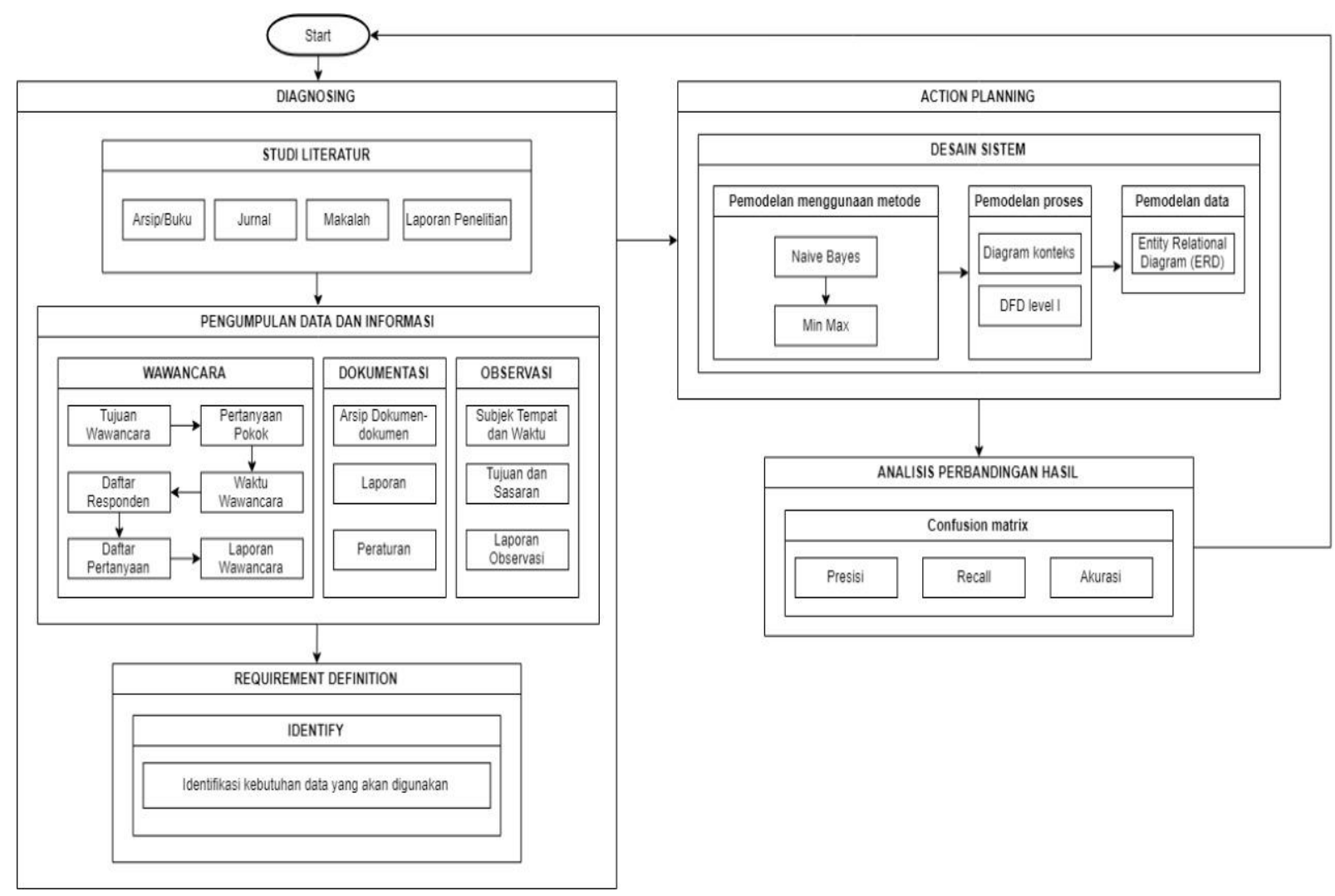

\section{Gambar 1. Metode Penelitian} berikut:

Tahapan-tahapan proses penentuan makanan pendamping ASI dalam penelitian ini sebagai

a. Diagnosing

Pada tahapan ini dilakukan studi literatur yaitu dengan merujuk kepada jurnal, prosiding, makalah, buku, dan laporan tugas akhir yang relevan dengan penelitian ini. Selanjutnya dilakukan pengumpulan data dan informasi.

b. ActionPlanning

Pada tahapan ini dilakukan desain sistem dan software, meliputi pemodelan metode Naive Bayes dan Metode Min Max, pemodelan proses Diagram konteks dan DFD level 1, pemodelan menggunakan metode Naive Bayes dan metode Min Max

c. Evaluating

Pada tahapan ini dilakukan perbandingan antara dua algoritma, sehingga diperoleh hasil perbandingannya. Pengukuran kinerja meliputi tingkat akurasi, nilai Presisi, dan nilai Recall yang berupa nilai angka yang menunjukkan kinerja yaitu dengan menggunakan counfision matrix.

\section{HASIL DAN PEMBAHASAN}

\subsection{Requerments Definition}

Pada tahap Requirements definition atau definisi persayaratan ini dilakukan untuk identifikasi kebutuhan data yang akan digunakan dalam penelitian ini,dalam hal ini data yang akan digunakan adalah data ibu-ibu dan dan bayi dari 14 Posyandu Kota Yogyakarta. Data set yang digunakan diperoleh dari fakta dari responden. Fakta yang digunakan ada 18 fakta yang di simbolkan dengan F. Sedangkan Hipotesa ada 6 yang di beri kode H. kemudian dikonsultasikan dengan pakar dan dijadikan dasar untuk pembobotan. Data set disajikan pada Tabel 1. 
Tabel 1.Data Set

\begin{tabular}{|c|c|c|c|}
\hline No & Responden & Fakta & $\begin{array}{c}\text { Rekomendasi } \\
\text { Pakar }\end{array}$ \\
\hline 1 & Dwi Nuryanti & F3, F9, F15, F16, F17, F18 & $\mathrm{H} 6$ \\
\hline 2 & Novita & $\mathrm{F} 2, \mathrm{~F} 4, \mathrm{~F} 10, \mathrm{~F} 11, \mathrm{~F} 12, \mathrm{~F} 14$ & $\mathrm{H} 5$ \\
\hline 3 & Agustin & $\begin{array}{l}\text { F2, F5, F10, F11, F12, F13, F14, } \\
\text { F15 }\end{array}$ & $\mathrm{H} 4$ \\
\hline 4 & Septi Handayani & F1, F4, F5, F6, F7, F8, F9, F11, F12 & $\mathrm{H} 2$ \\
\hline 5 & Diah Ayu & $\begin{array}{l}\text { F2, F5, F10, F11, F12, F13, F14, } \\
\text { F17 }\end{array}$ & $\mathrm{H} 4$ \\
\hline 6 & Wahyuni & F2, F6, F10, F12, F13, F14, F18 & $\mathrm{H} 4$ \\
\hline 7 & Dian Ananda Sari & F1, F4, F5, F6, F7, F8, F9, F10, F15 & $\mathrm{H} 1$ \\
\hline 8 & Irma Rachmawati & F1, F4, F5, F7, F8, F9, F13 & H1 \\
\hline 9 & Fitri Endang Lestari & F2, F10, F11, F13, F14, F18 & $\mathrm{H} 5$ \\
\hline 10 & DianUtari P & F2, F10, F12, F13, F14, F18 & $\mathrm{H} 3$ \\
\hline 11 & Nila & $\begin{array}{l}\text { F3, F4, F10, F11, F15, F16, F17, } \\
\text { F18 }\end{array}$ & $\mathrm{H} 5$ \\
\hline 12 & Retno Dwi A & F2, F7, F8, 10, F11, F14 & $\mathrm{H} 3$ \\
\hline 13 & Aprillia S & F1, F4, F5, F6, F7, F8, F9, F14 & $\mathrm{H} 1$ \\
\hline 14 & Dedys T & F3, F6, F7, F14, F14, F15, F18 & $\mathrm{H} 6$ \\
\hline 15 & Vitri Anita & F2, F10, F11, F13, F14 & $\mathrm{H} 4$ \\
\hline 16 & Nuari $\mathrm{R}$ & F1, F4, F5, F6, F7, F8, F9 & $\mathrm{H} 2$ \\
\hline 17 & Dinta Annisa M & F3, F8, F15, F16, F17, F18 & $\mathrm{H} 5$ \\
\hline 18 & Ruli Nur & F1, F4, F6, F7, F8, F9 & $\mathrm{H} 2$ \\
\hline 19 & Subekti & F3, F9, F15, F16, F17 & H6 \\
\hline 20 & Dina Setyowati & F3, F15, F16, F17, F18 & $\mathrm{H} 4$ \\
\hline 21 & Isna Hanifah & F2, F9, F10, F11, F14 & $\mathrm{H} 3$ \\
\hline 22 & L Sepriani N & F3, F15, F17, F18 & H6 \\
\hline 23 & Sintha & F2, F10, F11, F12, F13 & $\mathrm{H} 3$ \\
\hline 24 & Iva $\mathrm{K}$ & F1, F4, F5, F6, F7, F8, F9 & H1 \\
\hline 25 & Feny $\mathrm{H}$ & F3, F16, F17, F18 & H6 \\
\hline 26 & Dara Widiyastuti & F3, F15, F16, F17, F18 & $\mathrm{H} 6$ \\
\hline 27 & Margiyati & F1, F4, F5, F6, F7, F8, F9 & $\mathrm{H} 2$ \\
\hline 28 & Febriani P & F3, F15, F16, F17, F18 & $\mathrm{H} 6$ \\
\hline 29 & Siti Romlah & F2, F10, F11, F12, F13, F14 & $\mathrm{H} 4$ \\
\hline 30 & Suenip & F1, F5, F6, F7, F8 & $\mathrm{H} 2$ \\
\hline
\end{tabular}

Keterangan:

$\mathrm{F}=$ merupakan fakta

$\mathrm{H}=$ merupakan hipotesa

\subsection{Perancangan Database}

Rancangan database yang direkomendasikan pada peneltian ini dimana terdapat 5 entity yakni admin untuk menampung data admin, rekomendasi yang menyimpan data jenis makanan yang dapat 
dijadikan rekomendasi, fakta yang digunakan untuk menyimpan data faktor apa saja yang perlu diperhatikan dalam memberikan rekomendasi makanan, entity makanan untuk menyimpan data contoh menu makanan, serta entity bobot yang berfungsi untuk menyimpan nilai probabilitas kemunculan fakta terhadap rekomendasi, seperti Gambar 2 berikut ini.

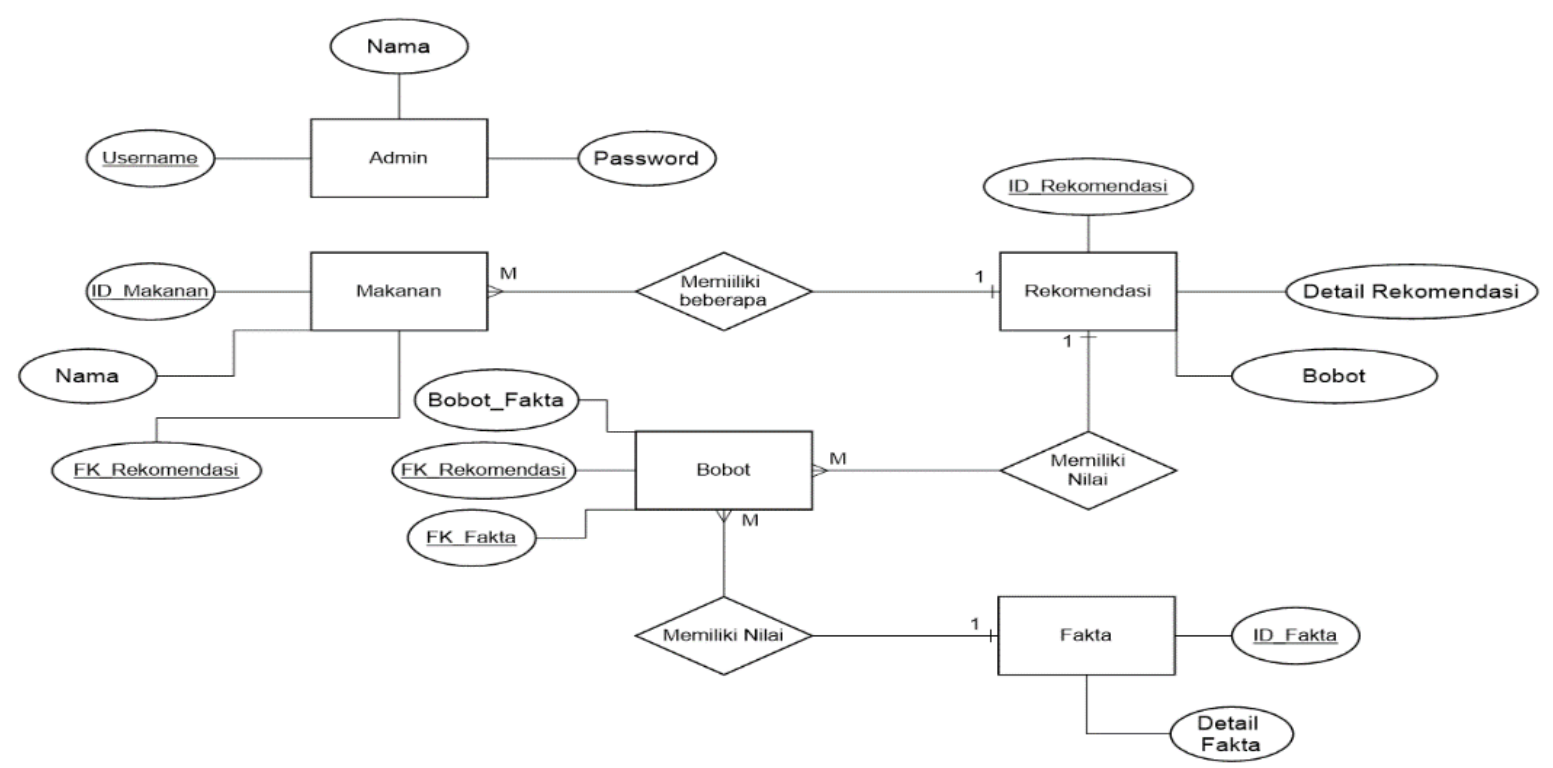

Gambar 2. Rancangan Entity Relation Diagram

\subsection{Rancangan Proses}

Pada tahapan ini dilakukan pemodelan proses dimana di sini digunakan diagram konteks,sebagaimana ditunjukkan Gambar 3.

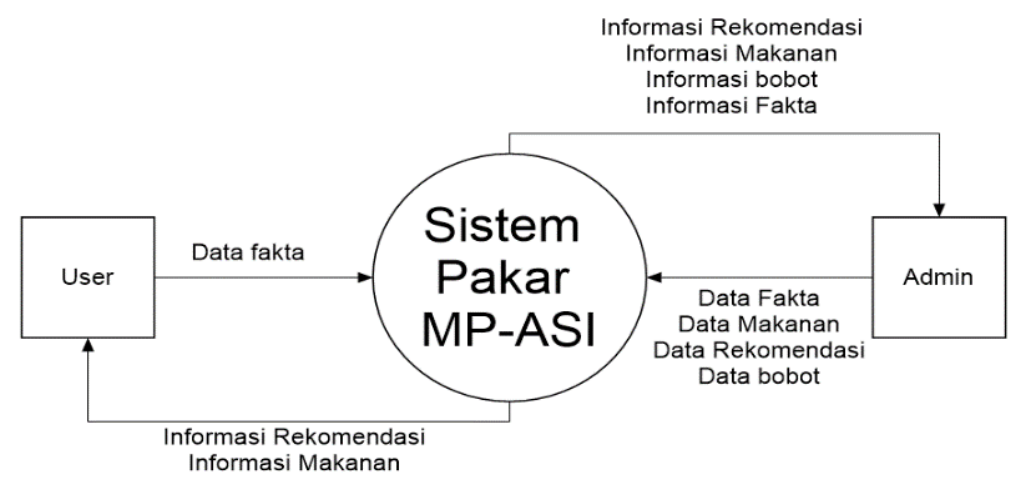

Gambar 3. Diagram Konteks

level 1 untuk mambantu dalam pendeskripsian dan desain sistem perangkat lunak yang akan digunakan dalam penelitian ini sebagaimana di jelaskan pada Gambar 4. 


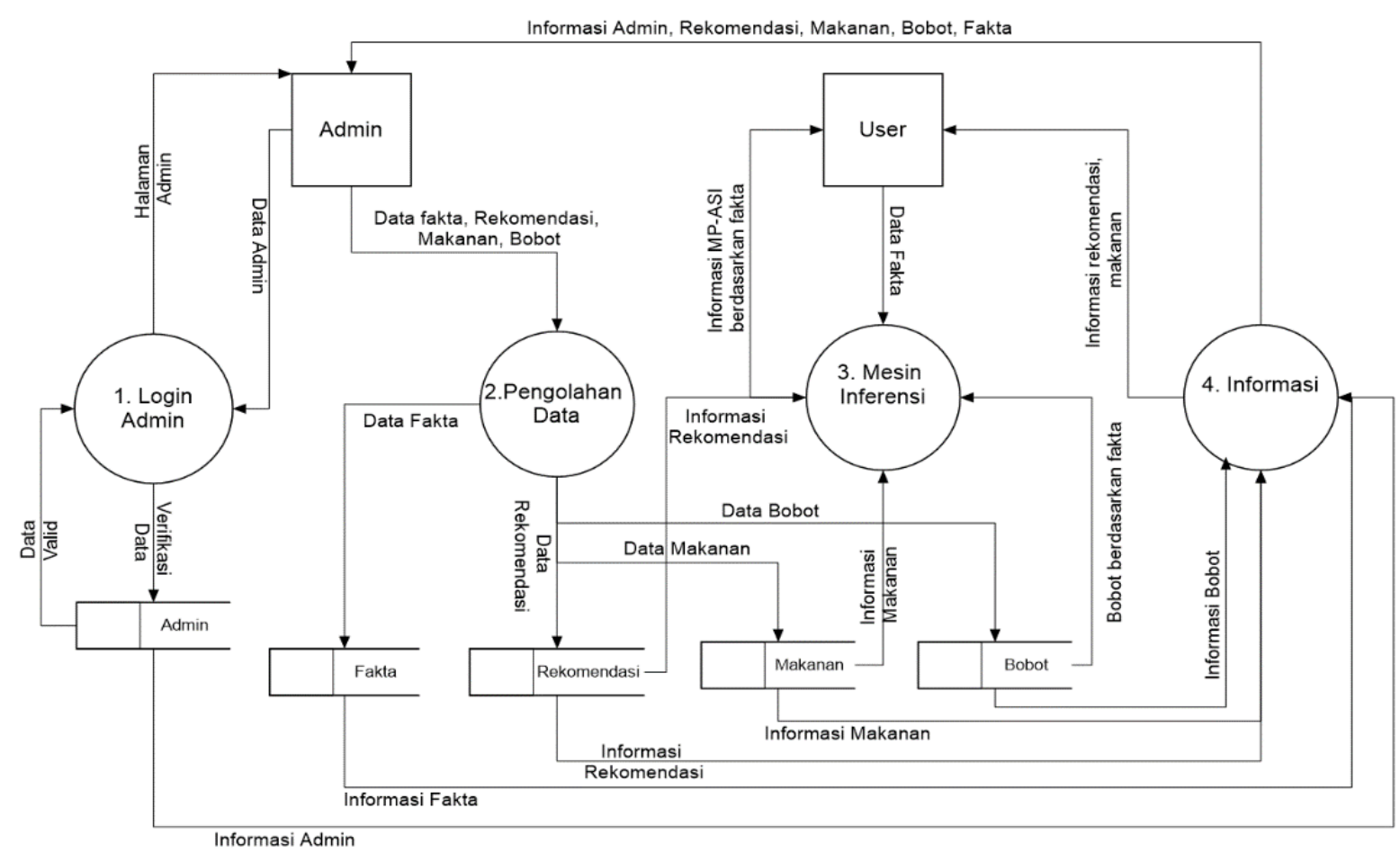

Gambar 4.Rancangan DFD Level 1

\subsection{Basis Pengetahuan}

\section{a. Metode Naive Bayes}

Nilai probabilitas kemunculan $\mathrm{H} 1$ dan $\mathrm{H} 2$ berdasarkan F1 sebesar 1.00 yang dapat diartikan berdasarkan dataset yang ada fakta satu akan berpengaruh besar pada kemunculan rekomendasi jenis makanan puree, sedangkan nilai F1 tidak memiliki pengaruh terhadap kemungkinan kemunculan $\mathrm{H} 3$, H4, H5 dan H6 karena memiliki nilai probabilitas 0. Berikut merupakan Tabel 2 merupakan probabilitas kemunculan hipotesa.

Tabel 2. Probabilitas kemunculan

\begin{tabular}{|l|l|l|l|l|l|}
\hline \multicolumn{5}{|c|}{ Probabilitas Kemunculan Hipotesa } \\
\hline H1 & H2 & H3 & H4 & H5 & H6 \\
\hline 0,133333 & 0,16667 & 0,133333 & 0,2 & 0,133333 & 0,233333 \\
\hline 0,1333 & 0,1667 & 0,1333 & 0,2 & 0,1333 & 0,2333 \\
\hline
\end{tabular}

\section{b. Metode Naive Bayes Dan Min Max}

Setelah diketahui bahwa nilai probabilitas kemunculan hipotesa puree pada dataset sebesar $13 \%$ atau 4 dari 30 data yang menjadi dataset menghasilkan rekomendasi jenis makanan puree. Nilai tersebut selanjutnya dijadikan dasar dalam perhitungan model naive bayes dan min max menggunakan persamaan (1).

Keterangan :

$$
P(H i \mid F)=\frac{P(H i) x P(H i)}{\sum_{k=1}^{n} P(H k) x P(H k)}
$$

$\mathrm{P}(\mathrm{Hi} \mid \mathrm{E})=$ Probabilitas Hi dikatakan benar berdasarkan fakta F.

$\mathrm{P}(\mathrm{F} \mid \mathrm{Hi})=$ Pprobabilitas fakta $\mathrm{E}$ terhadap hipotesa $\mathrm{Hi}$

$\mathrm{P}(\mathrm{Hi}) \quad=$ Pprobabilitas munculnya hipotes $\mathrm{Hi}$, tanpa memandang fakta apapun.

$\mathrm{n} \quad=$ Jumlah hipotesa.

Kemudian dilakukan klasifikasi dengan menggunakan algoritma naive bayes dimana diketahui fakta pada data testing pertama yaitu F1, F2, F4, F7, F9. 
langkah pertama adalah mencari nilai yang ada pada persamaan (2).

Keterangan :

$$
\sum_{k=1}^{n} \quad P(H i) x P(H i)
$$

$\mathrm{P}(\mathrm{Hi})=$ Probabilitas kemunculan $\mathrm{Hi}$ diperoleh berdasarkan keseluruhan data pada dataset tanpa memperhatikan fakta.

a) $(\mathrm{P}(\mathrm{F} 3 \mid \mathrm{H} 1) \times \mathrm{P}(\mathrm{F} 9 \mid \mathrm{H} 1) \times \mathrm{P}(\mathrm{F} 15 \mid \mathrm{H} 1) \times \mathrm{P}(\mathrm{F} 16 \mid \mathrm{H} 1) \times \mathrm{P}(\mathrm{F} 17 \mid \mathrm{H} 1) \times \mathrm{P}(\mathrm{H} 1))+(\mathrm{P}(\mathrm{F} 3 \mid \mathrm{H} 2) \times$ $\mathrm{P}(\mathrm{F} 9 \mid \mathrm{H} 2) \times \mathrm{P}(\mathrm{F} 15 \mid \mathrm{H} 2) \times \mathrm{P}(\mathrm{F} 16 \mid \mathrm{H} 2) \times \mathrm{P}(\mathrm{F} 17 \mid \mathrm{H} 2) \times \mathrm{P}(\mathrm{H} 2))+(\mathrm{P}(\mathrm{F} 3 \mid \mathrm{H} 3) \times \mathrm{P}(\mathrm{F} 9 \mid \mathrm{H} 3) \times$ $\mathrm{P}(\mathrm{F} 15 \mid \mathrm{H} 3) \times \mathrm{P}(\mathrm{F} 16 \mid \mathrm{H} 3) \times \mathrm{P}(\mathrm{F} 17 \mid \mathrm{H} 3) \times \mathrm{P}(\mathrm{H} 3))+(\mathrm{P}(\mathrm{F} 3 \mid \mathrm{H} 4) \times \mathrm{P}(\mathrm{F} 9 \mid \mathrm{H} 4) \times \mathrm{P}(\mathrm{F} 15 \mid \mathrm{H} 4) \times$ $\mathrm{P}(\mathrm{F} 16 \mid \mathrm{H} 4) \times \mathrm{P}(\mathrm{F} 17 \mid \mathrm{H} 4) \times \mathrm{P}(\mathrm{H} 4))+(\mathrm{P}(\mathrm{F} 3 \mid \mathrm{H} 5) \times \mathrm{P}(\mathrm{F} 9 \mid \mathrm{H} 5) \times \mathrm{P}(\mathrm{F} 15 \mid \mathrm{H} 5) \times \mathrm{P}(\mathrm{F} 16 \mid \mathrm{H} 5) \times$ $\mathrm{P}(\mathrm{F} 17 \mid \mathrm{H} 5) \times \mathrm{P}(\mathrm{H} 5))+(\mathrm{P}(\mathrm{F} 3 \mid \mathrm{H} 6) \times \mathrm{P}(\mathrm{F} 9 \mid \mathrm{H} 6) \times \mathrm{P}(\mathrm{F} 15 \mid \mathrm{H} 6) \times \mathrm{P}(\mathrm{F} 16 \mid \mathrm{H} 6) \times \mathrm{P}(\mathrm{F} 17 \mid \mathrm{H} 6) \times$ $\mathrm{P}(\mathrm{H} 6))$

b) $(0 \times 1 \times 0.25 \times 0 \times 0 \times 0.13)+(0 \times 0.80 \times 0 \times 0 \times 0 \times 0.16)+(0 \times 0.25 \times 0 \times 0 \times 0 \times 0.13)+(0$ x $0 \times 0.17 \times 0 \times 0,17 \times 0.2)+(0.50 \times 0 \times 0.50 \times 0.50 \times 0.50 \times 0.13)+(1 \times 0.29 \times 0.86 \times 0.71 \times$ $0,86 \times 0.233)$

c) $0+0+0+0+0+0.03$

d) $\mathbf{0 . 0 3}$

Berdasarkan persamaan 2 telihat bahwa jumlah probabilitas pada setiap hipotesa 0.03. Langkah selanjutnya adalah dilakukan perhitungan pada setiap hipotesa dimana digunakan persamaan (1).
a) $p\left(H_{1} \mid F_{3} F_{9} F_{15} F_{16} F_{17}\right)=\frac{(0 \times 1 \times 0.25 \times 0 \times 0 \times 0.13)}{0.3}=0$
b) $p\left(H_{2} \mid F_{3} F_{9} F_{15} F_{16} F_{17}\right)=\frac{(0 \times 0.80 \times 0 \times 0 \times 0 \times 0.16)}{0.3}=0$
c) $p\left(H_{3} \mid F_{3} F_{9} F_{15} F_{16} F_{17}\right)=\frac{(0 \times 0.25 \times 0 \times 0 \times 0 \times 0.13)}{0.3}=0$
d) $p\left(H_{4} \mid F_{3} F_{9} F_{15} F_{16} F_{17}\right)=\frac{(0 \times 0 \times 0.17 \times 0 \times 0.17 \times 0.2)}{0.3}=0$
e) $p\left(H_{5} \mid F_{3} F_{9} F_{15} F_{16} F_{17}\right)=\frac{(0.50 \times 0 \times 0.50 \times 0.50 \times 0.50 \times 0.13)}{0.3}=0$
f) $p\left(H_{6} \mid F_{3} F_{9} F_{15} F_{16} F_{17}\right)=\frac{(1 \times 0.29 \times 0.86 \times 0.71 \times 0.86 \times 0.233)}{0.3}=0.3$

\section{c. Pengujian}

Pengujian yang dilakukan dalam penelitian ini menggunakan confusion matrix. Confusion Parameter yang akan diuji yaitu akurasi, presisi, dan recall. Tabel 3 menunjukkan hasil pengujian.

Tabel 3. Hasil Pengujian

\begin{tabular}{|c|c|c|c|c|c|c|c|}
\hline \multicolumn{2}{|c|}{ Label } & \multicolumn{6}{|c|}{ Klasifikasi Naive Bayes } \\
\hline & & Puree & Mashed & Miched & Chopped & $\begin{array}{l}\text { Finger } \\
\text { Food }\end{array}$ & $\begin{array}{l}\text { Makanan } \\
\text { Keluarga }\end{array}$ \\
\hline \multirow{6}{*}{$\begin{array}{l}\text { Klasifikasi } \\
\text { Pakar }\end{array}$} & Puree & 3 & 0 & 0 & 0 & 0 & 0 \\
\hline & Mashed & 1 & 3 & 0 & 0 & 0 & 0 \\
\hline & Miched & 0 & 0 & 2 & 0 & 0 & 0 \\
\hline & Chopped & 0 & 0 & 0 & 4 & 0 & 0 \\
\hline & Finger Food & 0 & 0 & 0 & 0 & 1 & 0 \\
\hline & $\begin{array}{l}\text { Makanan } \\
\text { Keluarga }\end{array}$ & 0 & 0 & 0 & 0 & 0 & 6 \\
\hline \multicolumn{2}{|c|}{ Total Testing } & \multicolumn{4}{|c|}{20} & & \\
\hline
\end{tabular}

Persamaan yang digunakan untuk mencari nilai akurasi, presisi dan recall dapat dilihat pada persamaan (3) (4) (5). 


$$
\begin{array}{r}
\text { Akurasi }=\sum_{i=1}^{1} \quad \frac{\frac{T P i+T N i}{T P i+T N i+F P i+F n i}}{l} * 100 \% \\
\text { Presisi }=\frac{\sum_{i=1}^{l} T P i}{\sum_{i=1}^{l}(F P i+T P i)} * 100 \% \\
\text { Recall }=\frac{\sum_{i=1}^{l} T P i}{\sum_{i=1}^{l}(T P i+F N i)} * 100 \%
\end{array}
$$

Mencari akurasi menggunakan persamaan (3)

a) $(((\mathrm{TP} 1+\mathrm{TN} 1) / \mathrm{TP} 1+\mathrm{TN} 1+\mathrm{FP}+\mathrm{FN})+((\mathrm{TP} 2+\mathrm{TN} 2) / \mathrm{TP} 2+\mathrm{TN} 2+\mathrm{FP} 2+\mathrm{FN} 2)+$ $((\mathrm{TP} 3+\mathrm{TN} 3) / \mathrm{TP} 3+\mathrm{TN} 3+\mathrm{FP} 3+\mathrm{FN3})+\quad((\mathrm{TP} 4+\mathrm{TN} 4) / \mathrm{TP} 4+\mathrm{TN} 4+\mathrm{FP} 4+\mathrm{FN} 4))$ $((\mathrm{TP} 5+\mathrm{TN} 5) / \mathrm{TP} 5+\mathrm{TN} 5+\mathrm{FP} 5+\mathrm{FN} 5)+((\mathrm{TP} 6+\mathrm{TN} 6) / \mathrm{TP} 6+\mathrm{TN} 6+\mathrm{FP} 6+\mathrm{FN} 6)) / \mathrm{I}) * 100 \%$

b) $(((3+0) / 3+0+0+0)+((3+0) / 3+0+0+1)+((2+0) / 2+0+0+0)+((4+0) / 4+0+0+0))+((1+0) / 1+0+0+0))$ $+((6+0) / 6+0+0+0)) / 6) * 100 \%$

c) $((1+0.75+1+1+1+1) / 6) * 100 \%=(5.75 / 6) * 100 \%=0.9583 * 100 \%=95,83 \%$

Mencari Presisi dengan persamaan (4)

a) (( TP1 + TP2 + TP3 + TP4+ TP5 + TP6)/((FP1 + TP1) +(FP2 +TP2 ) +( FP3 + TP3 ) + ( FP4 + TP4 ) +( FP5 + TP5 $)+($ FP6 + TP6 $)) * 100 \%$

b) $((3+3+2+4+1+6) /((0+3)+(1+3)+(0+2)+(0+4)+(0+1)+(0+6))) * 100 \%=(19 / 20) * 100 \%=95 \%$

Mencari Recall dengan persamaan (5)

a) $((\mathrm{TP} 1+\mathrm{TP} 2+\mathrm{TP} 3+\mathrm{TP} 4+\mathrm{TP} 5+\mathrm{TP} 6) /((\mathrm{TP} 1+\mathrm{FN} 1)+(\mathrm{TP} 2+\mathrm{FN} 2)+(\mathrm{TP} 3+\mathrm{FN} 3)+(\mathrm{TP} 4+\mathrm{FN} 4)+(\mathrm{TP} 5+$ FN5 $)+($ TP6 + FN6) $)) * 100 \%$

b) $\quad((3+3+2+4+1+6) /((3+0)+(3+1)+(2+0)+(4+0)+(1+0)+(6+0))) * 100 \%=(19 / 20) * 100 \%=95 \%$

Setelah melihat hasil evaluasi yang telah dilaksanakan, terlihat bahwa dari 20 eksperimen diperoleh 19 hasil eksperimen yang cocok dengan pakar, dan 1 hasil eksperimen yang tidak cocok, dengan demikian diperoleh tingkat akurasi sebesar 95,83\%, nilai presisi sebesar 95\% dan nilai recall sebesar $95 \%$. Tidak ada perbedaan yang terjadi pada hasil pemodelan naive bayes dengan naive bayes dan min max, maka nilai akurasi, presisi dan recall tidak ada perbedaan.

\section{PENUTUP}

Pada penelitian sistem pakar penentuan makanan pendamping ASI menggunakan metode Min Max dan Naive Bayes telah berhasil di ujicoba. Hasil dari pengujian tingkat performa akurasi, presisi, recall menunjukan Min-Max Normalization tidak memiliki pengaruh terhadap metode nä̈ve bayes, karena pembobotan pada nä̈ve bayes sudah dalam bentuk scala 0-1. Berdasarkan hasil uji pada 20 responden, algoritma naive bayes classifier dan nä̈ve bayes classifier dengan Min-Max normalization berhasil memberikan rekomendasi 18 dari 20 data yang sesuai dengan hasil rekomendasi dari pakar. Algoritma naive bayes memberikan akurasi sebesar 95,83\%, presisi sebesar 95\% dan recall sebesar 95\% dalam memberikan rekomendasi jenis makanan pendamping ASI.

\section{REFERENSI}

[1] L. Mufida, T. D. Widyaningsih, and J. M. Maligan, "Prinsip Dasar Makanan Pendamping Air Susu Ibu ( MP-ASI ) untuk Bayi 6 - 24 Bulan: Kajian Pustaka," J. Pangan dan Agroindustri, vol. 3, no. 4, pp. 1646-1651, 2015.

[2] Departemen Kesehatan, Pedoman Umum Pemberian Makanan Pendamping Air Susu Ibu (MPASI). 2006.

[3] P. Yu et al., "Food groups consumed by infants and toddlers in urban areas of China," Food Nutr. Res., vol. 60, pp. 1-12, 2016.

[4] C. C. Ciptohartono, "Algoritma Klasifikasi Naive Bayes untuk Menilai Kelayakan Kredit," 
Manaj. Sist. Inf., vol. 1, no. 2, 2016.

[5] A. Jananto, "Algoritma Naive Bayes untuk Mencari Perkiraan Waktu Studi Mahasiswa," Teknol. Inf. Din., vol. 18, no. 1, pp. 9-16, 2013.

[6] R. A. Rahman, "Algoritma Naive Bayes untuk Mencari Perkiraan Waktu Training Studi Mahasiswa," E-Jurnal Med., vol. 6, no. 3, 2017.

[7] Y. S. Nugroho, "Data Mining Menggunakan Algoritma Naive Bayes Untuk Klasifikasi Kelulusan Mahasiswa Universitas Dian Nuswantoro," in SENATEK, 2013, pp. 1-10.

[8] Kusrini, Sistem Pakar Teori Dan Aplikasi. Yogyakarta: Andi Offset, 2006.

[9] M. Arhami, Konsep Dasar Sistem Pakar. Yogyakata: Andi Offset, 2005.

[10] S. R. Medise BE, Buku pintar bayi. Yogyakata, 2011.

[11] S. F. Rodiansyah and E. Winako, "Klasifikasi Posting Twitter Kemacetan Lalu Lintas Kota Bandung Menggunakan Naive Bayesian Classification," IJCCS, vol. 6, no. 1, pp. 91-100, 2012.

[12] B. V Indriyono, E. Utami, and A. Sunyoto, "Pemanfaatan Algoritma Porter Stemmer Untuk Bahasa Indonesia Dalam Proses Klasifikasi Jenis Buku," Buana Inform., vol. 45, no. 4, pp. 427-437, 2015.

[13] M. Sokolova and G. Lapalme, "A systematic analysis of performance measures for classification tasks," Inf. Process. Manag., vol. 45, no. 4, pp. 427-437, 2009.

[14] I. S. Sitanggang and M. H. Ismail, "Classification model for hotspot occurrences using a decision tree method," Geomatics, Nat. Hazards Risk, vol. 2, no. 2, pp. 111-121, 2011. 